\title{
Web Based Fosti Information System at Muhammadiyah University of Surakarta
}

\author{
$1^{\text {nd }}$ Nendy Akbar Rozaq Rais, $2^{\text {st }}$ Aini Zahra, \\ ${ }^{1,2}$ Institute Technology Business AAS Indonesia The College of Economics AAS Surakarta \\ ${ }^{1,2}$ Jl. Slamet Riyadi No. 361 Windan, Makamhaji, Kartasura, Sukoharjo, Indonesia \\ 1 ab.terate@gmail.com, ${ }^{2}$ ainizahra2@gmail.com,
}

\begin{abstract}
The student unit activity is an institution to achieve goals by holding events within the institution. FOSTI is one of the student activity units on the campus of the Muhammadiyah University of Surakarta that uses a web-based information system, of course in this application to make it easier to collect data or register for events being held. The purpose of this final semester assignment is to find out how to make or design an application system and train to analyze the existing system and evaluate the deficiencies in the system to the user. The registration process for event participants is done manually, often incorrectly in recording or data collection of event participants and creating piles of data in the form of papers, allowing data to be inserted due to negligence on the part of the committee. To solve this problem, it is necessary to have a registration application system. Making this system using the framework system Laravel Based Framework. Used to find easy alternatives. The method in this management information system uses Laravel Based. Making a system in a program with the PHP programming language, the process of registering events held by the laravel based method can facilitate the registration and data collection process, which previously used the manual method which took quite a long time. The method in this research uses the method of observation, interviews, and literature study. for designing the system using Contex Diagram, HIPO, and DAD. The purpose of this study is to find out how to make or design an application system and train to analyze existing systems and evaluate the deficiencies of the system to the user. The final result in the registration process and event data collection is in the form of types of events in the FOSTI organization, Muhammadiyah University of Surakarta and participant data reports.
\end{abstract}

Keywords : Information Systems, Student Activities, Framework.

\section{INTRODUCTION}

InPlease In the student activity unit, computers have a big role in the event registration system. Therefore, it encourages student activities to produce and improve information and services that are more accurate, relevant and timely. With the progress of the times, humans need something that is simple and fast in carrying out activities. One of which is the problem of registering an event. Participants who wish to register must go to the event registration site (secretariat) provided by the committee. With the existence of a web-based information system application, an application that uses the Laravel Based Framework is expected to be able to assist in registering or registering an event online and producing more practical results.

\subsection{Formulation of the problem}

In accordance with the above background, the formulation of the problem to be resolved in this study is how to design a management information system using a Laravel Based Framework.

\subsection{Restricting the problem}

To avoid widespread in the discussion, the discussion of this research problem is:

1. Application Using Laravel Based Framework for Registration of Events and Simplifying Data Collection.

2. The restrictions are specifically related to the registration menu for events that are in the socialization.

3. The database used is MySQL / Maria db.

\subsection{Destination}

The purpose of this final semester project is to find out how to create or design an application system and train to analyze the existing system and evaluate the deficiencies in the system to the user.

\section{RESEARCH METHODS}

In obtaining information and data in analyzing this system requires the following methods:

2.1. Method of collecting data

The following data collection methods are as follows:

1. Interview

In this interview method, the writer interviewed the head of the web and network division, Wahyu Suryaji, with the hat developing an event registration information system at UKM Fosti at UMS.

2. Observation

This observation stage observes how the event registration process is held at UKM Fosti.

3. Literature review

Literature study is looking for references through books or scientific journals related to the system.

\subsection{Systems Development Method}

The following methods in system development are as follows:

1. System Planning

Creating flows, determining methods, determining results.

2. System analysis

The stage of determining the destination, determining the user, designing the database, managing the routing.

3. System Design

The design stage is Context Diagram, HIPO, DAD, and Input Output Design. 
International Journal of Computer and Information System (IJCIS)

Peer Reviewed - International Journal

Vol : Vol. 01, Issue 02, August 2020

e-ISSN : 2745-9659

https://ijcis.net/index.php/ijcis/index

4. System Implementation

This system uses the PHP programming language, the database uses MySQL or Maria $\mathrm{db}$ and uses a framework with a view controller model.

5. System Testing

In this testing phase using testing functionality.

\subsection{Management information System}

A management information system is a system designed to provide decision-oriented information by planning, monitoring, and assessing organizational activities in the form of a framework at all stages. Management information system is a system that aims to provide information to simplify the process of operation, management, and decision making within an organization[3].

\subsection{Student activity units}

The student activity unit is a student organization where students who have the same interests, hobbies and creativity gather. The student activity unit is a forum for extracurricular activities for students to develop certain interests, talents and expertise such as dance, music, drama and others. The student activity unit is in a university which is supervised by a supervisor and consists of many students who come from different departments and faculties[4].

\subsection{Laravel Framework}

The definition of framework according to Naista is a basic conceptual structure used to solve or handle a complex problem. In short, a framework is a container or framework for a website to be built. By using this framework, the time spent making the website is shorter and makes it easier to make repairs.

One of the frameworks that are widely used by programmers is the laravel framework. Laravel is a PHP based open source framework, and uses the concept of model - view - controller. Laravel is licensed under the MIT License by using Github as a place to share code to run it[5].

\subsection{Online Web Apps}

The web is a collection of web pages that are interrelated. Web is a system that contains a variety of information in the form of text, images, audio and video and can be accessed via a device called a web browser. Web is a collection of information both static and dynamic which consists of pages created [4]

\subsection{PHP Programming Language}

PHP singkatan dari PerlHypertext Preprocessor yang merupakan bahasa server-side scripting yang berada pada halaman Hypertext Markup Language (HTML) yang ditujukan untuk membantu programmer menulis halaman web secara mudah dan cepat. PHP bersifat server-side berarti semua pengerjaan script dilakukan di server dan hasilnya dikirim ke browser. PHP merupakan bahasa pemrograman yang memprogram situs web dinamis, yaitu mampu mengoperasikan web secara terus-menerus. Hypertext Preprocessor (PHP) merupakan perangkat lunak opensource yang berada dibawah aturan general purpose lisences[5].

\subsection{Database MySQL / Maria db}

MySQL is a derivative of Structured Query Language (SQL), SQL is a database operation that can be done easily and automatically. MySQL is in charge of organizing and managing data in the database. MySQL is a relationship software that can be used for free. MySQL is a database management system software on a multi-user Structured Query Language (SQL). MySQL is the most stable database management used as data storage media[6].

\subsection{Previous research}

"Batik Information System Design in Toko Andini Plupuh". This research is about the problems faced by the batik shop Andini Plupuh, namely the processing of sales process data processing and processing is still manual using Microsoft Excel. By paying attention to various problems and the development of technology, the authors propose to design a web-based sales information system that can connect store admins and consumers so as to improve sales performance and data processing. The method used in the design or development with SDLC. The design of this information system is expected to make it easier for companies to promote with the internet and the admin can process data on goods to make it easier, faster and more accurate in reporting.[1]

E-Commerce Batik at Batik Center, Pilang Masaran Village. This research is about the problems faced by the village of Pilang Masaran in promoting batik products. With current technological developments, the researcher proposes to design an e-commerce that will make it easier for batik entrepreneurs in Pilang Masaran village to promote and further increase sales results. The method used is data collection and system development. The e-commerce design is expected to help the Pilang Masaran community in promoting and increasing sales.[2]

\section{RESULT AND ANALYSIS}

In the discussion, discussing the results of research in the form of system design as a whole are as follows:

\subsection{Computerized Systems Analysis}

Problems At this time the event participant registration process, participants use a manual system in the form of writing in a notebook then typed into Microsoft Excel. This method causes problems, such as the loss of participant data because the data storage sometimes moves places, so for that this process is not very supportive of data collection and very ineffective in registering event registration data. In order to make it easier to record the Student Activity Unit of the University of Muhammadiyah Surakarta, it is necessary to develop a web-based or online registration system, using this web-based system will minimize errors in data recording.

\subsection{System planning}

This stage is the stage of system development and design of a new system to provide an overview for the system program that will build the new system.

1. Contex Diagram

Contex Diagram(CD) for the event registration information system are as follows: 
International Journal of Computer and Information System (IJCIS)

Peer Reviewed - International Journal

Vol : Vol. 01, Issue 02, August 2020

e-ISSN : 2745-9659

https://ijcis.net/index.php/ijcis/index

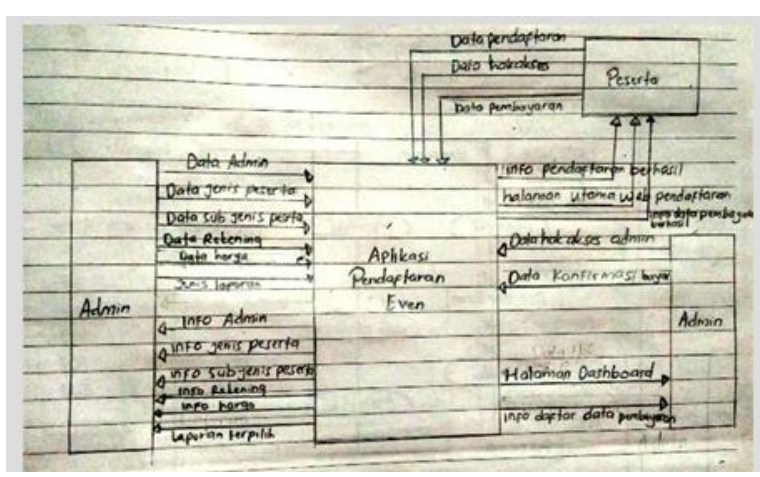

Figure 1. Context Diagram

\section{2. $\mathrm{HIPO}$}

HIPO (Input Process Output Hierarchy) is a system development tool and system documentation technique in programs. The most important goal of HIPO is to produce correct output and meet user requirements.

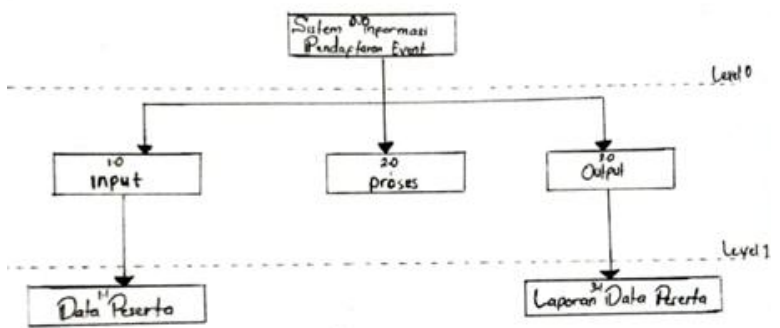

Figure 2. HIPO

3. DAD (Data Flow Diagram)

Data Flow Diagrams(DAD) is a flow diagram that describes the flow from data to the system, DAD helps to understand the system in a logical, structured and clear way. Here is DAD level 0 for event registration information system.

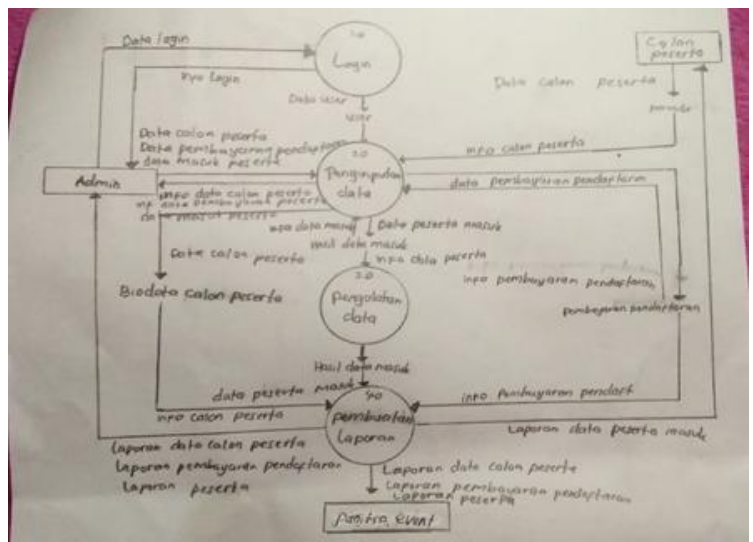

Figure 3. Data Flow Diagram

\subsection{System Implementation}

System implementation is the process of making a system in the form of designing an event participant registration information system application:

1. Login page
This data input display is used to input potential event participant data.

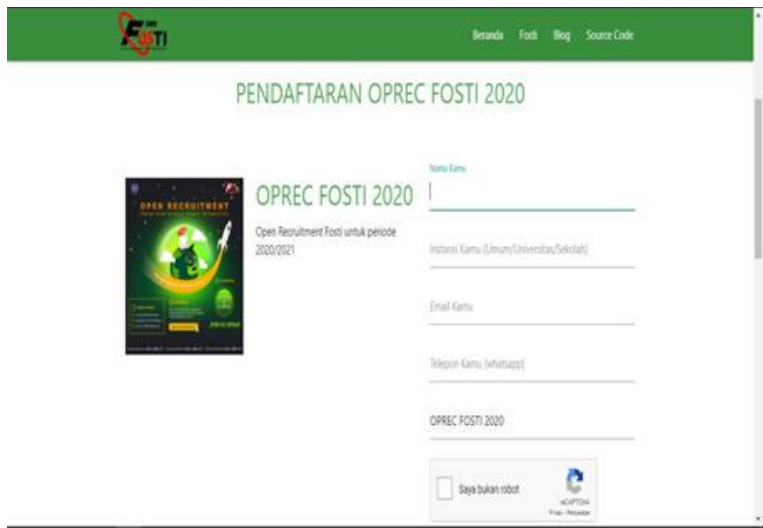

Figure 4. Participant Data Input Form

2. Event Setting Display

The event setting form display is used to add a new event.

a. New Events page

The following is a look at the settings for adding a new event as follows

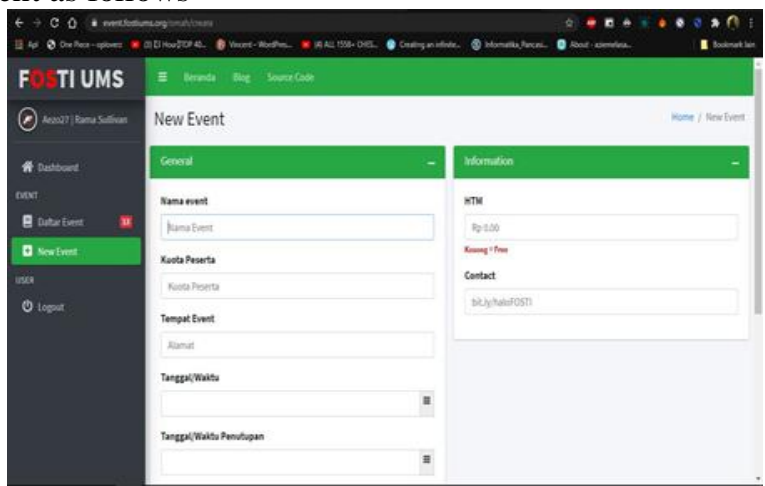

Figure 5. New Event page

3. Event List Result Display

Display of the results of the list of events held by UKM Fosti at UMS.

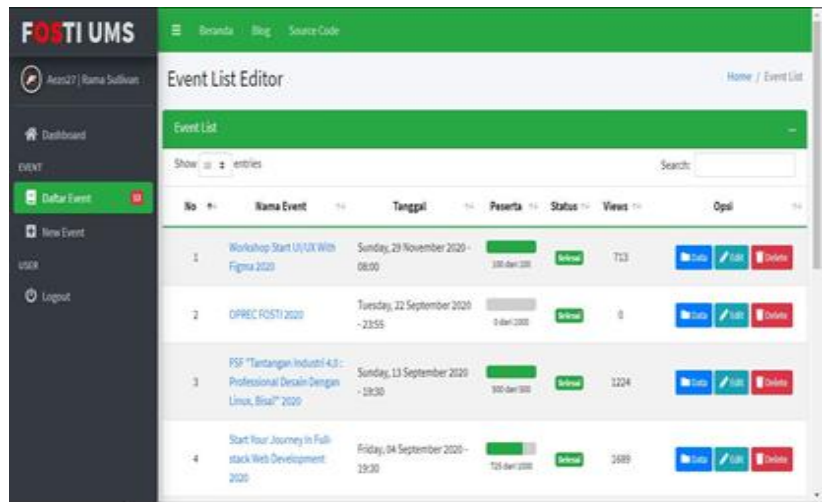

Figure 6. Event List Page

The following are the results of the data reports on participants who have registered for the event as follows: 
International Journal of Computer and Information System (IJCIS)

Peer Reviewed - International Journal

Vol : Vol. 01, Issue 02, August 2020

e-ISSN : 2745-9659

https://ijcis.net/index.php/ijcis/index

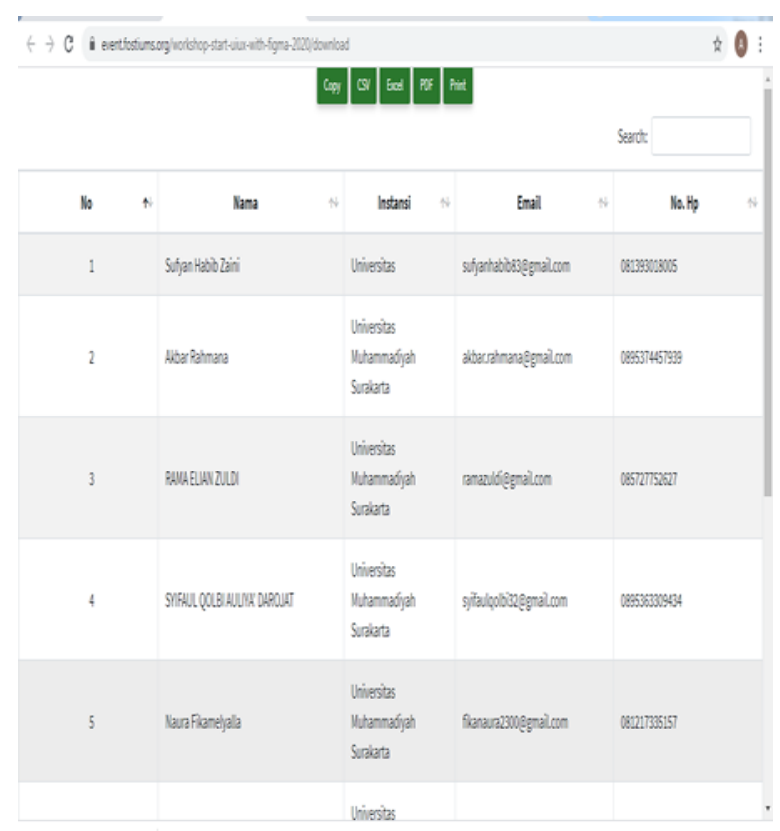

Figure 7. Participant Data Results

\subsection{System Testing}

Testing is a system test process at the end which is also useful for testing the system. This system testing uses two system tests, namely functionality testing and questionnaire testing.

\subsubsection{Functionality Testing}

Functionality testing uses the Black Box, which is useful for knowing the output results in each form in the program system. the following system test results whether this system is in accordance with what is expected.

Table 1. Functionality Test

\begin{tabular}{|c|c|c|c|c|}
\hline NO & $\begin{array}{l}\text { Komponen } \\
\text { yang di uji }\end{array}$ & Skenario & $\begin{array}{l}\text { Hasil yang } \\
\text { diharapkan }\end{array}$ & $\begin{array}{c}\text { Hasil } \\
\text { pegujian }\end{array}$ \\
\hline 1 & $\begin{array}{c}\text { Halaman } \\
\text { login admin }\end{array}$ & $\begin{array}{c}\text { Masukan email dan } \\
\text { pssword }\end{array}$ & $\begin{array}{c}\text { Muncul } \\
\text { pesan } \\
\text { berhasil } \\
\text { login dan } \\
\text { kemudian } \\
\text { tampil } \\
\text { halaman } \\
\text { admin }\end{array}$ & Benar \\
\hline 2 & $\begin{array}{l}\text { Halaman } \\
\text { Input event }\end{array}$ & Masukan data event & $\begin{array}{l}\text { Setelah } \\
\text { input event } \\
\text { selesi } \\
\text { muncul } \\
\text { pesan data } \\
\text { berhasil di } \\
\text { simpaan }\end{array}$ & Benar \\
\hline 3 & $\begin{array}{l}\text { Halaman } \\
\text { input } \\
\text { peserta }\end{array}$ & $\begin{array}{c}\text { Masukan data yang } \\
\text { di minta dengan } \\
\text { benar }\end{array}$ & $\begin{array}{c}\text { Setelah } \\
\text { masukan } \\
\text { data } \\
\text { kemudian } \\
\text { muncul } \\
\text { pesan data } \\
\text { berhasil di } \\
\text { simpan }\end{array}$ & Benar \\
\hline 4 & $\begin{array}{c}\text { Halaman } \\
\text { pengambila } \\
\text { n data }\end{array}$ & $\begin{array}{c}\text { Download data } \\
\text { peserta }\end{array}$ & $\begin{array}{c}\text { Setelah } \\
\text { download } \\
\text { selesai } \\
\text { muncul } \\
\text { pesan } \\
\text { pengambila } \\
\text { ndata } \\
\text { berhasil }\end{array}$ & Benar \\
\hline
\end{tabular}

\subsubsection{Quizoner Testing}

In this questionnaire test, a google form was made which contained several questions about the registration system application and then the questions were filled in by the chairman of the web and network that manages the registration application, and the questions were filled in by the application user or participant who registered, then the author also filled out the question, because The author has practiced opening the registration system.

\section{Stage 1}

In the process of determining the questionnaire test for this system, it involved 3 respondents. This can be seen in table 2. Below.

Table 2. Respondents Data

\begin{tabular}{|c|c|c|c|c|c|c|}
\hline \multicolumn{7}{|c|}{ Kuisoner Penggunaan Sistem Informasi Pendaftaran Event } \\
\hline \multirow{2}{*}{ No } & \multirow{2}{*}{ Pertanyaan } & \multicolumn{5}{|c|}{ Skot } \\
\hline & & 2 & 4 & 8 & $s$ & 10 \\
\hline 1 & $\begin{array}{l}\text { Apakah aplikasi sistem } \\
\text { pendaftaran yang anda } \\
\text { gunakan mempermudah } \\
\text { dalam melakukan kerjanya? }\end{array}$ & & & & & $\checkmark$ \\
\hline 2 & $\begin{array}{l}\text { Apakah dalam kerjanya } \\
\text { sistem pendaftaran berjalan } \\
\text { dengan baik? }\end{array}$ & & & & $\nu$ & \\
\hline 3 & $\begin{array}{l}\text { Apakah aplikasi sistem } \\
\text { pendaftaran berjalan sesuai } \\
\text { dengan kinerjanya? }\end{array}$ & & & & & $\checkmark$ \\
\hline 4 & 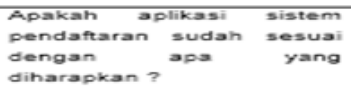 & & & & & $\nu$ \\
\hline 5 & $\begin{array}{l}\text { Jika masin ada kendala. } \\
\text { Apakah bisa ditangani? }\end{array}$ & & & & 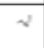 & \\
\hline \multicolumn{6}{|c|}{ Juoviab vilai } & 46 \\
\hline & Rata - rata ailai & & & & & 9 \\
\hline
\end{tabular}

\subsubsection{SWOT analysis}

Registration system application

Table 3. SWOT analysis

\begin{tabular}{|l|l|}
\hline Type of analysis & Weighted value \\
\hline Strength & 4,3 \\
\hline Weakness & 2.75 \\
\hline Oppartunities & 3.5 \\
\hline Threat & 4.5 \\
\hline
\end{tabular}

\section{Aplikasi Sistem Pendaftaran}

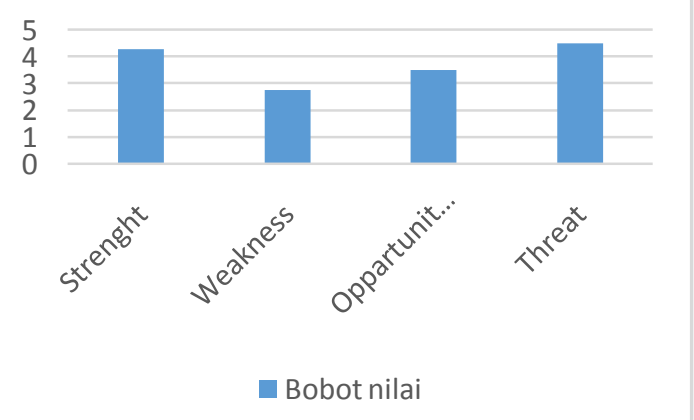

Figure 8. SWOT Analysis 
International Journal of Computer and Information System (IJCIS)

Peer Reviewed - International Journal

Vol : Vol. 01, Issue 02, August 2020

e-ISSN : 2745-9659

https://ijcis.net/index.php/ijcis/index

With the SWOT analysis of this Registration Information System application, the authors can conclude that this application is quite helpful, efficient and effective in registration and data collection and it is very possible for further system development in the process without requiring internet connectivity and can be opened at any time with good security. further improved in accordance with the development of technology, information and communication. Finally, I hope this application can run even better with application optimization, increasing data input and output and increasing data security, so that the application can be trusted as a supporting application efficiently. This application system is actually quite good, but there are still a few updates to the process. security and connectivity.

\section{CONCLUSION}

At the end of this pentup contains the conclusions and research suggestions, which are as follows :

\subsection{Conclusion}

The information system for Student Activity Units at FOSTI, from the web-based system design of data can be concluded as follows:

1. This system is a source of information for the Student Activity Unit

2. The designed system can be opened via a web browser using a cellphone or computer.

3. Prospective participants can register themselves directly through this information system without having to come to the place.

4. With the participant registration information system will make data collection easier so that it can improve performance in the Student Activity Unit.

So the conclusion of this registration system is:

1. Efficient and effective system will make it easier to register and collect data

2. From the questionnaire test given to 3 people with the author, with an average value of 8,80 , olh because of that this application is suitable to be used in helping the registration process and data collection of this event and is good enough.,

3. Testing is functionally running normally and in accordance with the system.

\subsection{Suggestion}

After analyzing the registration information system, the writer can conclude the shortcomings of the system, the internet connection constraints when registering and data collection, and in the registration payment system which is still ambiguous in the process. The suggestion for this application is that in this process it is better if it can be accessed without an internet network and as well as adding the card print function of participants who have registered and paid as proof that the participant has actually followed the registration procedure. And add a menu for payment / upload proof of payment to make it easier for participants to show proof of payment. Black.

That is the suggestion that the author has made. It is hoped that this system can facilitate student activity units in managing registration event, Sehingga kegiatan mahasiswa Fosti Universitas muhammadiyah Surakarta dapat berjalan lebih efektif dan efisien lagi.

\section{REFERENCES}

[1] N. A. R. Rais and T. F. Efendi, "Perancangan Sistem Informasi Batik di Toko Andini Plupuh," vol. 2, no. November 2020, pp. 1-6, 2020.

[2] N. A. R. Rais and U. Fadlilah, "E-Commerce Batik di Sentra Batik Desa Pilang Masaran,” 2015.

[3] Pratama,F.A \& Gunawan, D.(2015). Sistem Informasi Pengajuan Proposal dan Laporan Pertanggungjawaban Berbasis WEB Pada Biro Administrasi Kemahasiswaan dan Alumni Universitas Kristen Petra.Jurnal Infra,3(1),114-120.

[4] Sadewa,I.,\& Siahaan, K. (2016). Analisis dan Perancangan Sistem Informasi Unit Kegiatan Mahasiswa (UKM) Berbasis Web pada Universitas Batanghari.Jurnal Manajemen Sistem Informasi, 1(2), 135-146.

[5] Ana. J. Oktasari., \& Denny, K. (2020). Perancangan Sistem Informasi Manajemen Kegiatan Mahasiswa Berbasis Web.

[6] Usada. E. Yuniarsyah, Y., \& Rifani, N. (2012).Rancang Bangun Sistem Informasi Perkuliahan Berbasis Jquery Mobile Dengan Menggunakan PHP Dan MySQLJurnal Infotel. 4(2). 40-51.

[7] Prasipta, R., Wibawanto, H., \& Mulwinda, A. (20170. DESIGN OF LETTER ADMINISTRATION MANAGEMENT INFORMATION SYSTEM USING LARAVEL FRAMEWORK IN ELECTRICAL ENGINEERING DEPARTMENT.

[8] Ma'arif, S. (2015). Management Information System (SIM) as one of the services in improving school quality: Multi case study at SMA BPPT Darul Ulum and MAN Unggulan Tambak Beras Jombang. LPPM UIN Sunan Ampel Surabaya.

[9] Naista. (2017). Design a Management System Using the Laravel Based Framework for the Department of Informatics Engineering.

[10] Muqorobin, Muqorobin, Siti Rokhmah, Isnawati Muslihah, and Nendy Akbar Rozaq Rais. "Classification of Community Complaints Against Public Services on Twitter." International Journal of Computer and Information System (IJCIS) 1, no. 1 (2020).

[11] K. Kusrini, E. T. Luthfi, M. Muqorobin and R. W. Abdullah, "Comparison of Naive Bayes and K-NN Method on Tuition Fee Payment Overdue Prediction," 2019 4th International Conference on Information Technology, Information Systems and Electrical Engineering (ICITISEE), Yogyakarta, Indonesia, 2019, pp. 125-130, doi: 10.1109/ICITISEE48480.2019.9003782.

[12] Muqorobin, M., Hisyam, Z., Mashuri, M., Hanafi, H., \& Setiyantara, Y. (2019). Implementasi Network Intrusion Detection System (NIDS) Dalam Sistem Keamanan Open Cloud Computing. Majalah Ilmiah Bahari Jogja, 17(2), 1-9.

[13] Muqorobin, M., Apriliyani, A., \& Kusrini, K. (2019). Sistem Pendukung Keputusan Penerimaan Beasiswa dengan Metode SAW. Respati, 14(1).

[14] Abdullah, Robi W., et al. "Keamanan Basis Data pada Perancangan Sistem Kepakaran Prestasi Sman Dikota Surakarta." Creative Communication and Innovative Technology Journal, vol. 12, no. 1, 2019, pp. 13-21. 
International Journal of Computer and Information System (IJCIS)

Peer Reviewed - International Journal

Vol : Vol. 01, Issue 02, August 2020

e-ISSN : 2745-9659

https://ijcis.net/index.php/ijcis/index 